\title{
Reforming abortion services in the UK: less hypocrisy, more acknowledgment of complexity
}

\section{Sandy Goldbeck-Wood}

Editor-in-Chief, Journal of Family Planning and Reproductive Health Care, Faculty of Sexual \& Reproductive Healthcare, London, and Clinical Lead for Abortion Services, Cambridge University Hospitals,

Cambridge, UK

\section{Correspondence to} Dr Sandy Goldbeck-Wood, Journal of Family Planning and Reproductive Health Care, Faculty of Sexual \& Reproductive Healthcare, 27 Sussex Place London NW1 4RG, UK. goldbeckwood@doctors.org.uk

Accepted 2 December 2016
To cite: Goldbeck-Wood S. J Fam Plann Reprod Health Care 2017:43:3-4.

\section{BACKGROUND}

A moment when the world's most powerful country has just elected one of its most anti-abortion presidents might seem an odd time for UK abortion care providers to be seeking the liberalisation of Britain's abortion law. But 50 years on from the passing of the 1967 Abortion Act, abortion care in the UK is heading towards a crisis, and practitioners are undeterred by the political climate. This is reflected in the founding of a new support organisation for service providers, the British Society for Abortion Care Providers (BSACP) ${ }^{1}$ a new campaign for legal reform by the UK's largest service provider, the British Pregnancy Advisory Service (BPAS), ${ }^{2}$ active consultation processes on abortion care quality and legal reform within the Royal College of Obstetricians and Gynaecologists (RCOG) and the Faculty of Sexual \& Reproductive Healthcare (FSRH), and a constant stream of material submitted to this journal. ${ }^{3-13}$

\section{CHALLENGES}

Among many challenges women seeking abortion face, inequitable access, inadequate numbers of appropriately trained staff, stigmatisation, and a culture of exceptionalism, or ghettoisation, have often been highlighted. ${ }^{14}{ }^{15}$ Much abortion care in the UK is provided outside the National Health Service in specialist organisations, excluding students and trainees, among them the potential service providers of the future. As well as reinforcing stigma, this deprives trainees of valuable learning opportunities. It is noteworthy that while the RCOG has offered an Advanced Training Skills Module in abortion care since 2007, fewer than $1 \%$ of trainees completing such modules have taken it (RCOG, personal communication, November 2016).

\section{OPPORTUNITIES}

For practitioners not excluded by conscientious objection - a right which within limits must be upheld and respected $^{16}$ - abortion care offers an important learning environment. Here, we encounter the same women whose babies we may also deliver at other times, but at a different stage in their reproductive life-course. We gain confidence and skill in early pregnancy examination and safe uterine intervention, and see medical and surgical care in a complex ethical, legal and biopsychosocial context. This teaches high-level, transferrable consulting skills. All practitioners need to be able to facilitate ethically complex, patientcentred decision making with interest, confidence and self-reflection.

\section{ABORTION LAW}

Problems of access and stigma, familiar worldwide, are compounded in the UK by an abortion law that is now widely seen as not fit for purpose. Framed as a medically sanctioned defence against a piece of criminal law passed in $1861,{ }^{17}$ UK law is out of step with technical advances in safe medical abortion, the trend away from paternalism towards patient-centred and nurse-led services, and current UK social values. ${ }^{18}$ Hence, while many women now attend our services in early pregnancy believing they have a right to make their own choice, as they would in most of Europe $^{19}$ - British law still requires the identification of serious physical or mental health risk by two doctors not necessarily qualified in psychological disciplines, who may not know the woman personally. There is broad consensus among practitioners that this is hypocritical and anachronistic.

\section{REFLECTION}

But if the law is to be reformed as BPAS, the Royal College of Nursing, the Royal 
College of Midwives, and other women's health organisations propose, space must first be made for reflective debate. That debate needs to place women's wellbeing centre stage, but also acknowledge ethical complexity. Agreeing how far a woman's autonomy can be extended, and what processes can best safeguard this core value while also acknowledging its ethical context, will require a degree of mutual respect which has been lacking. We need to move beyond the kind of violent communication that sees a minority of so-called 'pro-life' campaigners bullying women seeking abortion, and a minority of so-called 'pro-choice' campaigners refusing to acknowledge moral complexity. Achieving social consensus will be no less demanding a process than that faced by each individual woman forced to weigh serious and conflicting concerns in considering whether to end her pregnancy.

\section{ACKNOWLEDGING COMPLEXITY}

In joining this debate, we must not as practitioners fall into the trap of focusing narrowly on clinical concerns and conceding the moral debate to extremists - an argument made cogently in a new book reviewed in this issue. ${ }^{11}$ For many women seeking abortion, acknowledging it as a sad and serious event seems an essential part of reaching a decision that they can live with and learn from. For others, the decision is more straightforward, and individual difference needs to be respected. But where ambivalence, guilt, regret or other 'difficult' feelings do exist, we should not, in our eagerness to avoid 'abortion-negativity', suppress these. Abortion care must not be an obstacle course, but neither should it be a conveyor belt.

\section{WHAT IS IN THIS JOURNAL ISSUE?}

One casualty of exceptionalism and factionalism is good evidence to inform care quality. While two articles in this journal issue highlight specific areas in which UK abortion care could improve - cervical preparation before, ${ }^{10}$ and contraceptive provision after, ${ }^{8}$ abortion - a systematic review highlights a much broader problem with agreement over care quality indicators. ${ }^{3}$ A linked commentary calls for valid quality criteria to be set in the UK. ${ }^{4}$ Looking at an Australian experience of abortion law reform, a mixed methods study of practitioners' views cautions that despite empowering women and increasing clarity and safety for practitioners, it failed to address stigma, access and workforce sustainability. ${ }^{5}$

Other contributions remind us that apparently neutral language can reinforce stigma, ${ }^{7}$ and of the 'inverse care law', which compounds disadvantage for poor women, wherever services are poorly accessible. ${ }^{12}$

So your contributions on abortion keep flooding in, because abortion care remains a high-volume, underresearched and under-integrated area of women's healthcare. And 2017 is an excellent time for practitioners to be challenging hypocrisy and exceptionalism in UK abortion care, and leading respectful debate centred on women's needs, with complexity acknowledged.
Competing interests None declared.

Provenance and peer review Commissioned; internally peer reviewed.

\section{REFERENCES}

1 British Society for Abortion Care Providers (BSACP). https:// bsacp.org.uk/ [accessed 28 November 2016].

2 British Pregnancy Advisory Service (BPAS). 'We Trust Women' campaign website. http://www.wetrustwomen.org.uk/ [accessed 28 November 2016].

3 Dennis A, Blanchard K, Bessenaar T. Identifying indicators for quality abortion care: a systematic literature review. J Fam Plan Reprod Health Care 2017;43:8-16.

4 Lord J. Quality and abortion services. J Fam Plan Reprod Health Care 2017;43:17.

5 Keogh LA, Newton D, Bayly C, et al. Intended and unintended consequences of abortion law reform: perspectives of abortion experts in Victoria, Australia. J Fam Plan Reprod Health Care 2017;43:18-24.

6 Sheldon S. Abortion law reform in Victoria: lessons for the UK. J Fam Plan Reprod Health Care 2017;43:25.

7 Hoggart L, Newton VL, Bury L. Repeat abortion: a phrase to be avoided? Qualitative insights into labelling and stigma. J Fam Plan Reprod Health Care 2017;43:26-30.

8 Cameron ST, Glasier A, Johnstone A. Comparison of uptake of long-acting reversible contraception after abortion from a hospital or a community sexual and reproductive healthcare setting: an observational study. J Fam Plan Reprod Health Care 2017;43:31-36.

9 Goldbeck-Wood S. The moral case for abortion [Book review]. J Fam Plan Reprod Health Care 2017;43:70.

10 Lyus R. Cervical preparation prior to second-trimester surgical abortion and risk of subsequent preterm birth. J Fam Plan Reprod Health Care 2017;43:70-71.

11 D'Souza R. My reflections on abortion law reform. J Fam Plan Reprod Health Care 2017;43:72-74.

12 Zafra-Tanaka JH, Merino-Garcia N, Taype-Rondan A. Poverty and abortion complications in Peru. J Fam Plan Reprod Health Care 2017;43:80-81.

13 Maierhofer W. 24 Weeks (24 Wochen, 2016) [Film review]. J Fam Plan Reprod Health Care 2017;43:80-81.

14 Doran F, Nancarrow S. Barriers and facilitators of access to first-trimester abortion services for women in the developed world: a systematic review. J Fam Plann Reprod Health Care 2015;41:170-180.

15 Astbury-Ward E. Abortion 'on the NHS': The National Health Service and abortion stigma. J Fam Plann Reprod Health Care 2015;41:168-169.

16 FIGO Committee for the Ethical Aspects of Human Reproduction and Women's Health. Ethical guidelines on conscientious objection. Int J Gynecol Obstet 2006;92:333-334.

17 The National Archives. Offences Against the Person Act 1861. http://www.legislation.gov.uk/ukpga/Vict/24-25/100/contents [accessed 28 November 2016].

18 British Social Attitudes. NatCen Social Research 33rd Edition. 2015. http://www.bsa.natcen.ac.uk/latest-report/britishsocial-attitudes-33/introduction.aspx [accessed 28 November 2016].

19 Library of Congress. Abortion Legislation in Europe. https:// www.loc.gov/law/help/abortion-legislation/europe.php [accessed 28 November 2016]. 


\section{Erratum: 'Reforming abortion services in the UK: less hypocrisy, more acknowledgment of complexity'}

Goldbeck-Wood S. Reforming abortion services in the UK: less hypocrisy, more acknowledgment of complexity J Fam Plann Reprod Health Care 2017;43:3-4.

An editorial in our January issue contained the erroneous statement that the Royal College of Nursing (RCN) supported the British Pregnancy Advisory Service's We Trust Women campaign - a campaign seeking abortion law reform in the UK. It was pointed out to us that RCN has no such policy. The Journal wishes to apologise unreservedly to the RCN for this error in a sensitive area of debate.

J Fam Plann Reprod Health Care 2017;43:95. doi:10.1136/jfprhc-2016-101696corr1

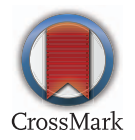

